STUDI

FRANCESI

\section{Studi Francesi}

Rivista quadrimestrale fondata da Franco Simone

165 (LV | III) | 2011

LA RAPPRESENTAZIONE DELLA MADRE NELLA

LETTERATURA FRANCESE DEL NOVECENTO a cura di Dario Cecchetti e Michele Mastroianni

\title{
François Rouget, Ronsard et les figures de la persuasion
}

\section{Dario Cecchetti}

\section{(2) OpenEdition \\ Journals}

\section{Edizione digitale}

URL: http://journals.openedition.org/studifrancesi/4964

DOI: 10.4000/studifrancesi.4964

ISSN: 2421-5856

\section{Editore}

Rosenberg \& Sellier

\section{Edizione cartacea}

Data di pubblicazione: 1 décembre 2011

Paginazione: 630

ISSN: 0039-2944

\section{Notizia bibliografica digitale}

Dario Cecchetti, «François Rouget, Ronsard et les figures de la persuasion», Studi Francesi [Online], 165 (LV | III) | 2011, online dal 30 novembre 2015, consultato il 09 janvier 2021. URL: http://

journals.openedition.org/studifrancesi/4964 ; DOI: https://doi.org/10.4000/studifrancesi.4964

Questo documento è stato generato automaticamente il 9 janvier 2021.

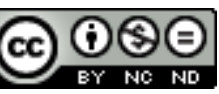

Studi Francesi è distribuita con Licenza Creative Commons Attribuzione - Non commerciale - Non opere derivate 4.0 Internazionale. 


\title{
François Rouget, Ronsard et les figures de la persuasion
}

\author{
Dario Cecchetti
}

\section{NOTIZIA}

FRANÇOIS ROUGET, Ronsard et les figures de la persuasion, «Revue des Amis de Ronsard», XXII, 2009, pp. 41-63.

1 Nelle prese di posizione di Ronsard rispetto alla natura retorica del linguaggio poetico intravvediamo una concezione della poesia il cui scopo ultimo sarebbe quello di 'persuadere' il lettore ad aderire a una rappresentazione del mondo. François Rouget, in questo saggio, data la scarsità di testi teorici di Ronsard, interroga le sue opere poetiche, riguardo alla nozione, appunto, di 'persuasione', nella convinzione che lo studio delle figure ronsardiane che la raffigurano (Pytho, Mercurio, Promessa, Opinione, ecc.) possa portare elementi di risposta circa il modo in cui il poeta concepisce il linguaggio, nelle sue possibilità persuasive e nei suoi limiti. Pertanto attraverso l'analisi di alcune figure mitiche della persuasione e della menzogna viene indagata la rappresentazione ronsardiana della parola poetica, della sua efficacia ma anche della sua ambiguità. 